\title{
Dampak Pertambangan Batubara Dalam Kehidupan Sosial Ekonomi Masyarakat di Desa Apung Kecamatan Tanjung Selor Kabupaten Bulungan
}

\author{
Jimmy $\mathbf{N}^{\mathbf{1}}$, K. Rapiandi Isak Merang ${ }^{2}$ \\ Program Studi Administrasi Negara, Fakultas Ilmu Sosial dan Ilmu Politik \\ Universitas Kaltara \\ Jimmyborneo98@mail.com ${ }^{1}$, isakrapiandi88@gmail.com ${ }^{2}$
}

\begin{abstract}
ABSTRAK
Permasalahan dalam kajian penelitian yaitu bagaimana dampak pertambangan batubara bagi kehidupan sosial ekonomi masyarakat di Desa Apung Kecamatan Tanjung Selor Kabupaten Bulungan. Metode penelitian yaitu kualiatif deskriptif, dengan informan penelitian mencakup Kepala Desa Apung, Sekertaris Desa Apung, Tokoh masyarakat, dan masyarakat Desa Apung. Teknik pengumpulan data yaitu observasi, wawancara, dan dokumentasi. Analisis data yaitu reduksi data, penyajian data (data display), dan penarikan kesimpulan/verifikasi. Keabsahan data meliputi triangulasi sumber, triangulasi metode, dan perpanjangan waktu penelitian. Dampak pertambangan batubara bagi kehidupan sosial ekonomi masyarakat di Desa Apung yaitu keberadaan pertambangan batubara memberikan dampak positif terhadap sosial ekonomi masyarakat Desa Apung mencakup tersedianya lapangan pekerjaan bagi masyarakat setempat, meningkatkan ekonomi masyarakat lokal dengan cara memberikan bantuan: (1) budidaya ayam dan ikan lele, (2) memberikan bibit jeruk kepada masyaraat petani(3) memberikan bibit singkong gaja, (4) memberikan bantuan air bersi (penampung air), (5) memberikan bantuan sosial berupa sembako, (6) membangun inprastruktur berupa jalan dan infrastruktur, berupa perbaikan badan jalan desa, membuat jalan antara desa dan membangun lapangan olahraga, (7) memberikan bantuan pada kerja bakti/umum di desa Apung. Dampak positif selanjutnya yaitu meningkat usaha masyarakat lokal yaitu usaha sembako terus melonjak naik dan toko/atau jualan, meningkatkan usaha depo air, dan membuka usaha ketring. Dampak negatif adanya perusahaan pertambangan yaitu, penebangan hutan, hilangnya flora dan fauna, lahan untuk kegiatan pertanian berkurang, pencemaran terhadap beberapa aliran air, debu atau polusi udara, dan terjadinya sengketa lahan antara masyarakat.
\end{abstract}

Kata Kunci: Dampak, Pertambangan Batubara, Sosial Ekonomi, Masyarakat

ABSTRACT

The problem in the research study is how the impact of coal mining on the socioeconomic life of the community in Apung Village, Tanjung Selor District, Bulungan Regency. The research method is descriptive qualitative, with research informants including the Head of the Floating Village, the Secretary of the Floating Village, community leaders, and the community of the Floating Village. Data collection techniques are observation, interviews, and documentation. Data analysis, namely data reduction, data presentation (data display), and drawing conclusions / verification. The validity of the data included source triangulation, method triangulation, and research time extension. The impact of coal mining on the socioeconomic life of the people in Apung Village, namely the existence of coal mining has a positive impact on the socio-economic conditions of the Apung Village community, including the availability of jobs for the local community, improving the local community's economy by providing assistance: (1) chicken and catfish farming, (2) giving citrus seeds to the farming 
community (3) giving cassava seeds, (4) providing clean water (water storage), (5) provide social assistance in the form of basic necessities, (6) building infrastructure in the form of roads and infrastructure in the form of repair of village road bodies, build roads between villages and build sports fields, (7) provide assistance for community service / public work in Apung village. The next positive impact is the increase in local community business, namely the food business continues to increase and shop / or sales, increase water depot business, and open a ketring business. The negative impact of mining companies, namely, deforestation, loss of flora and fauna, reduced land for agricultural activities, pollution of several water flows, dust or air pollution, and land disputes between communities.

Keywords: Impact, Coal Mining, Socio-Economy, Society 


\section{PENDAHULUAN}

Keberadaan perusahaan pertambangan yang melakukan kegiatan eksploitasi batubara akan memberikan dampak positif dan negatif terhadap ekonomi, lingkungan dan sosial bagi masyarakat di sekitar areal pertambangan. Dampak adalah suatu perubahan yang terjadi sebagai akibat suatu aktivitas baik yang bersifat alamiah, kimia, fisik maupun biologi yang mempengaruhi sosial ekonomi masyarakat disekitarnya(Otto 2009).

Pertambangan batubara diharapkan dapat memberikan kontribusi bagi pemerintah dan meningkatkan kesejahteraan masyarakat setempat. Pertambangan batubara memberikan dampak yang baik bagi masyarakat jika perusahaan tersebut menerapkan Analisis Mengenai Dampak Lingkungan (AMDAL) dengan baik. Dampak positif bagi masyarakat dapat dilihat dai pendapatan dan bertambanya lapangan pekerjaan sehingga dapat mengurangi tingkat pengangguran pada suatu daerah.

Alas an untuk mengurangi tingkat pengangguran dan meningkatkan kesejahteraan masyarakat yang berada di lokasi perusahaan pertambangan batubara merupakan salah satu alasan pemerintah memberikan izin kepada perusahaan tambang. Namun disisi lain pemerintah dianggap kurang mengetahui terkait dampak negatif yang dirasakan oleh masyarakat daerah perusahaan pertambangan batubara. Dalam hal ini peran pemerintah tentu sangat penting untuk menerapkan kebijakan terkait dengan kepatuhan perusahaan dalam menerapkan AMDAL.

Selama ini, kebijakan pemerintah terkait pengelolaan dan pemanfaatan sumberdaya alam seperti sumberdaya batubara masih memprioritaskan keuntungan ekonomi dari pendapatan pajak dan royalty. Sedangkan kerusakan lingkungan akibat kegiatan pertambangan batubara masih diabaikan pemerintah, padahal lingkungan adalah aset penting yang harus jaga dan dipertahankan agar masyarakat dapat memenuhi kebutuhannya.

Aktifitas perusahaan tambang batubara di Desa Apung Kecamatan Tanjung Selor Kabupaten Bulungan menimbulkan dampak negatif seperti hilangnya satwa liar dan habitatnya, adanya perubahan ekosistem flora dan fauna dan dampak air bersih. Melihat dampak realita yang ditimbulkan, harus menjadi tanggung jawab perusahaan dan pemerintah dalam mengatasi dan mencega permasalahan pencemaran lingkungan. Dampak yang timbul disebabkan karena AMDAL belum berjalan dengan maksimal. Tahun 2012 pelaksanaan AMDAL sudah dilakukan namun seiring berjalannya waktu, AMDAL harus tetap menjadi prioritas perusahaan dan pemerintah untuk mencega terjadinya hal-hal negatif. Kegiatan AMDAL dilakukan secara terus menerus untuk menghindari supaya tidak terjadi pencemaran lingkungan.

Selain adanya dampak negatif yang dirasakan oleh masyarakat desa Apung, realita dampak positif keberadaan perusahaan tambang batubara PT Pesona Khatulitiwa (PKN) bagi kehidupan sosial ekonomi masyarakat di Desa Apung mengalami perubahan dengan adanya peningkatan kesejahteraan masyarakat lokal yang didukung dengan penerapan Corporate Social Responsibility (CSR) oleh perusahaan. Penerapan CSR sangat membantu masyarakat desa Apung terutama dalam bidang pendidikan dengan penyediaan kendaraan sekolah. Adanya kendaraan sekolah utuk anak-anak sekolah di desa Apung yang difasilitasi oleh perusahaan batubara meringankan biaya pendidikan. Kesejahteraan masyarakat lokal meningkat karena adanya kesempatan untuk membuka lapangan pekerjaan baru dan 
perusahaan juga memproritaskan tenaga kerja lokal sebagai kariawan pada PT Pesona Khatulitiwa (PKN).

Permasalahan yang dikaji dalam penelitian ini yaitu yaitu bagaimana dampak pertambangan batubara bagi kehidupan sosial ekonomi masyarakat di Desa Apung Kecamatan Tanjung Selor Kabupaten Bulungan?

Menurut (Salim,Hs 2012) pertambangan adalah sebagian atau seluruh tahapan kegiatan dalam rangka penelitian, pengelolaan dan pengusahaan mineral atau batubara yang meliputi penyelidikan umum, eksploitasi, studi kelayakan, kontruksi, pertambangan, pengolahan dan pemurnian, pengangkutan dan penjualan serta kegiatan pascatambang. Sedangkan menurut (Muchjidin 2006) batu bara adalah satuan batuan sedimen organic berasal dari penguraian sisa berbagai tumbuhan yang merupakan campuran yan heterogen antara senyawa organik dan zat organic yang menyatu di bawah beban strata yang menghimpitnya.

Keberadaan peratmbangan batubara memberikan dampak terhadap masyarakat lokal. Menurut Soemarwoto Otto (2009) dampak sebagai suatu perubahan yang terjadi sebagai akibat suatu aktivitas. Aktivitas tersebut dapat bersifat alamiah, baik kimia, fisik maupun biologi. Dampak dapat bersifat positif berupa manfaat, dapat pula bersifat negatif berupa resiko, kepada lingkungan fisik dan non fisik termasuk sosial ekonomi.

Dampak adalah perubahan lingkungan yang sangat mendasar yang diakibatkan oleh suatu usaha dan/ atau kegiatan, Pasal 22 ayat 1 Undang-undang Nomor 32 Tahun 2009 tentang perlindungan dan peneglolaan lingkungan hidup, menyatakan bahwa setiap kegiatan yang diperkirakan akan mempunyai dampak penting terhadap lingkungan, perlu disertai dengan dasar pertimbangan yaitu bahwa penilaian pentingnya dampak terhadap lingkungan atas dasar kemungkinan timbulnya dampak positif atau negatif tidak boleh dipandang sebagai faktor yang masing-masing berdiri sendiri, melainkan harus diperhitungkan bobotnya guna dipertimbangkan hubungan timbal baliknya untuk mengambil keputusan (Fatmawati;Budiman;Dyastari 2017).

Menurut UU Nomor 5 Tahun 1984 tentang perindustrian adalah kegiatan ekonomi yang mengolah bahan mentah, bahan baku, barang setengah jadi, dan/atau barang jadi menjadi barang dengan nilai yang lebih tinggi untuk penggunaannya, termasuk kegiatan rancang bangun dan perekayasaan industri. Pembangunan industri bertujuan untuk :

a. Meningkatkan kemakmuran dan kesejahteraan rakyat secara adil dan merata dengan memanfaatkan dana, sumber daya alam, dan/atau hasil budidaya serta dengan memperhatikan keseimbangan dan kelestarian lingkungan hidup;

b. Meningkatkan pertumbuhan ekonomi secara bertahap, mengubah struktur perekonomian ke arah yang lebih baik, maju, sehat, dan lebih seimbang sebagai upaya untuk mewujudkan dasar yang lebih kuat dan lebih luas bagi pertumbuhan ekonomi pada umumnya, serta memberikan nilai tambah bagi pertumbuhan industri pada khususnya;

c. Meningkatkan kemampuan dan penguasaan serta mendorong terciptanya teknologi yang tepat guna dan menumbuhkan kepercayaan terhadap kemampuan dunia usaha nasional;

d. Meningkatkan keikutsertaan masyarakat dan kemampuan golongan ekonomi lemah, termasuk pengrajin agar berperan secara aktif dalam pembangunan industri;

e. Memperluas dan memeratakan kesempatan kerja dan kesempatan berusaha, serta meningkatkan peranan koperasi industry,(Siska 2013). 
Terdapat beberapa dampak positif dari industri pertambangan batubara. Beberapa dampak positif tersbut diantaranya adalah :

a. Membuka daerah terisolasi dengan dibangunnya jalan pertambangan dan pelabuhan.

b. Sumber devisa Negara.

c. Sumber Pendapatan Asli Daerah (PAD).

d. Sumber energy alternatif, untuk masyarakat lokal.

e. Menampung masyarakat kerja (Djajadiningrat, Surya. 2001).

Musthopa (2008) dalam (Fitriyanti,Reno 2016) menjabarkan potensi manfaat ekonomi dengan hadirnya pertambangan dalam beberapa hal sebagai berikut : (1) Menjadi pionir roda ekonomi, (2) Mendorong pengembangan wilayah (3) Memberikan manfaat ekonomi regional dan nasional (4) Memberikan peluang usaha pendukung (5) Pembangunan infrastruktur baru (6) Memberikan kesempatan kerja (7) Membuka isolasi daerah terpencil (8) Meningkatan ilmu pengetahuan dengan transfer teknologi.

Menurut Hesperian (2013) dalam (Teuku Ade Fachlevi, Eka Intan Keumala Putri 2015) pertambangan menyebabkan kerusakan lingkungan karena melakukan kegiatanpembukaan lahan yang luas, menggali lubang yang dalam dan memindahkan tanah dalam jumlah besar. Selain itu, kegiatan pertambangan batubara dapat mengakibatkan masyarakat di sekitar terkena gangguan kesehatan berupa gangguan pernafasan akibat debu.

Menurut (Soerjono 2001) industri pertambangan juga berpotensi merusak lingkungan sosial, yaitu nilai-nilai sosial budaya lokal dan ekonomi masyarakat yang bermukim di wilayah tambang, mempengaruhi pola kepemilikan lahan, pemanfaatan dan penguasaan sumberdaya alam, pertumbuhan dan perkembangan fasilitas sosial yang pada gilirannya menurunkan tingkat kehidupan sosial dan ekonomi masyarakat.

\section{METODE PENELITIAN}

Jenis penelitian ini adalah kualitatif dengan pendekatan deskriptif. Kualitatif adalah angka penelitian ilmiah yang menyandarkan kebenaran pada sisi kriteria ilmu empiris yang berusaha untuk mengeksploritasi, mendeskripsikan, menjelaskan dan memprediksikan kejadian-kejadian pada setting sosial (Aan, Komariah dan Santori 2010).

Sumber Data yang digunakan dalam penelitian ini yaitu data primer, Kepala Desa Apung, Sekertaris Desa Apung, Tokoh masyarakat Desa Apung, Masyarakat Desa Apung yang bekerja di tambang, Karyawan perusahaan pertambangan batubara, dan data Data Sekunder berupa catatan data kearsipan yang dapat menunjang penelitian

Teknik pengumpulan data data-data yang diperlukan yaitu: Observasi, Wawancara, dan Dokumen yang dibutukan berupa dokumen (catatatan), video atau foto. Menurut Guba dan Lincoln dalam (Moleong 2007) record adalah setiap pernyataan tertulis yang disusun oleh seseorang/lembaga untuk keperluan pengujian suatu peristiwa atau menyajikan akunting.

Analisis data yang digunakan adalah analisis data model Interaktif melalui tahapantahapan yaitu: Pengumpulan Data, Reduksi data, penyajian data, dan penarikan Kesimpulan/Verifikasi dengan mencari makna setiap gejala yang diperolehnya dari lapangan, mencatat keteraturan dan konfigurasi yang mungkin ada, alur kausalitas dari fenomena, dan proposisi dengan didukungnya teori dan penyempurnaan teori maka dapat disimpulka (Sugiyono 2016) (Sugiyono 2013). 


\section{HASIL DAN PEMBAHASAN}

Keberadaan pertambangan barubara di Desa Apung tentu memberikan suatu dampak signifikan bagi kehidupan masyarakat, terutama dalam sosial ekonomi masyarakat. Berikut dampak keberadaan petambangan batubara di Desa Apung:

\section{Dampak Positif.}

Pertambangan batu bara yang ada di Desa Apung tentu membawa dampak yang positif yang dirasakan oleh masyarakat secara langsung ataupun tidak langsung. Dampak positif dengan keberadaan perusahaan pertambangan batubara dapat meningkatkan kesejahteraan masyarakat Desa Apung. Adapaun dampak positif tersebut mencakup:

a. Membuka Lapangan Pekerjaan

Sebelum adanya perusahaan batubara (PT. PKN), masyarakat lebih terfokus pada bidang pertanian namun hasil yang diperoleh dari kegiatan pertanian kurang memuaskan mengingat bahwa tanaman yang ditanam di daerah atau lokasi Desa Apung tidak subur karena panasnya batu bara di daerah tersebut. Masyarakat desa bersyukur dengan adanya perusahaan batubara (PT.PKN) sehingga dapat mengurangi penganguran dan menamba lapangan pekerjaan.

Salah satu kebijakan yang diterapkan oleh perusahaan batubara yang beroperasi di daerah Desa Desa Apung yaitu membuka lapangan pekerjaan bagi masyarakat setempat. Hal itu bertujuan untuk melaksanakan program CSR (Corporate Social Responsibility) oleh perusahaan pada masyarakat sekitar perusahaan pertambangan batu bara. Keberadaan pertambangan batubara di Desa Desa Apung tentu sangat dirasakan oleh masyarakat karena dapat memberikan nilai positif bagi masyarakat desa secara langsung untuk mendapatkan pekerjaan.

Masyarakat Desa Apung berpendapat bahwa mereka bisa bekerja di perusahaan batubara PT Pesona Khatulitiwa (PKN) yang disesuaikan dengan kebutuhan perusahaan. Masyarakat bekerja sebagai satpam atau security dan ada juga yang bekerja di bagian administrasi perusahaan. Terbuka lapangan pekerjaan memberikan kemudahan bagi masyarakat untuk mencari pekerjaan dan masyarakatpun mendapat pengalaman baru serta pendapatan yang lebih besar. Masyarakat memiliki pendapatan baru dan dapat meningkatkan kesejahteraan masyarakat secara langsung. Perusahaan menerapkan tanggung jawab sosial terhadap masyarakat Desa Apung dengan memproritaskan tenaga kerja dari desa, sehingga memudakan masyarakat untuk melamar pekerjaan di perusahaan batubara tersebut. Sebelum perusahaan batu bara masuk ke desa Desa Apung, masyarakat bekerja sebagai petani dan ada juga sebagai tukang bangunan dengan penghasilan tidak tetap.

Menurut (Djajadiningrat,Surya 2001) dampak positif industri dari pertambangan batubara di Indonesia adalah : membuka daerah terisolasi dengan dibangunnya jalan pertambangan dan pelabuhan, umber devisa negara, sumber pendapatan asli daerah (PAD), sumber energy alternatif, untuk masyarakat lokal, dan menampung masyarakat kerja.

Perusahaan batubara di Desa Apung membuka lapangan pekerjaan, atau memberikan kesempatan kerja kepada masyarakat sekitar, agar masyarakat tersebut merasa lebih dihargai, tetapi perusahaan tetap memberlakukan seleksi karyawan dengan 
standar kualifikasi penerimaan karyawan dalam perusahaan tersebut. Adanya lapangan kerjaan yang dibuka oleh perusahaan sangat diapresiasi baik sekali oleh masyarakat karena masyarakat bisa bekerja di perusahaan tersebut. Kesempatan yang diberikan perusahaan batubara kepada masyarakat untuk dapat bekerja di perusahaan dimanfaatkan dengan baik oleh masyarakat. Dari pendataan penduduk yang diperoleh diketahui bahwa jumlah karyawan swasta meningkat semenjak perusahaan batubara ada di Desa Apung.

Perubahan yang terjadi pada masyarakat secara ekonomi di desa Apung disebabkan adanya aktivitas kegiatan perusahaan batubara (PKN) Menurut Carley dan Bustelo yang dikutip oleh (Hadi, 2002), Dampak sosial ekonomi terdiri dari perubahan pendapatan, kesempatan berusaha dan pola tenaga kerja.

Membuka lapangan kerja kepada masyarakat lokal merupakan tanggung jawab sosial terhadap masyarakat desa Desa Apung. Contoh lain tanggung jawab sosial perusahaan untuk karyawan, khsusunya masyarakat Desa Apung, yaitu pihak perusahaan bisa memberikan reward atau suatu penghargaan kepada karyawan yang berprestasi atas kerja kerasnya di dalam perusahaan tersebut, dengan tujuan agar dapat memacu semangat kerja dari karyawan tersebut, jika karyawan tersebut bekerja keras terhadap perusahaan, maka pihak perusahaan pula yang diuntungkan.

b. Meningkatkan ekonomi masyarakat lokal

Masyarakat Desa Apung mayoritas petani dengan pendapatan yang secukupnya, bahkan ada sebagian masyarakat tidak mampu membiayai pendidikan anak mereka untuk melanjutkan pendidikan keperguruan tinggi karena keterbatasan ekonomi. Masyarakat senang dan terbantu dengan adanya perusahaan batu bara di Desa Apung yang membawa dampak positif bagi masyarakat. Dampak yang ditimbulkan secara langsung yaitu terhadap perekonomian masyarakat. Masyarakat dapat memenuhi kebutuhan sehari-hari dan mampu membiayai pendidikan anak mereka untuk menempu pendidikan.

Perusahaan batubara sudah berusaha melaksanakan tanggung jawab terhadap sosial atau masyarakat Desa Apung, seperti melakukan kegiatan yang dapat meningkatkan kesejahteraan masyarakat sekitar, memberikan beasiswa bagi anak tidak mampu di Desa Apung, bantuan pendidikan (beasiswa) bagi masyarakat desa Apung yang melanjutkan pendidikan. Selanjutnya bantuan pendidikan yang sangat bermanfaat bagi masyarakat yaitu dengan adanya fasilitas Angkutan Siswa Sekolah (ASS). Perusahaan batubara memberikan layanan angkutan 4 unit mobil untuk angkutan siswa. Angkutan siswa sekolah merupakan pemberian perusahaan batubara kepada masyarakat Desa Apung untuk mengatar dan menjemput siswa-siswi yang berasal dari Desa Apung. Bantuan transportasi tersebut sangat bermanfaat untuk ekonomi masyarakat karena masyarakat tidak dipusingkan lagi dengan beban transportasi pendidikan karena ada bantuan dari perusahaan batubara.

Peran perusahaan batubara dalam mingningkatkan kesejahteraan atau perekonomian masyarakat Desa Apung yaitu dengan menerapkan tanggung jawab sosial perusahaan terhadap masyarakat. Perusahaan batubara "berkomitmen membangun tenaga listrik sebagai media untuk meningkatkan kualitas kehidupan masyarakat, mengupayakan tenaga listrik menjadi pendorong kegiatan ekonomi dan menjalankan kegiatan usaha yang berwawasan lingkungan. Adanya saluran listrik yang fasilitasi oleh perusahaan batubara 
memberikan suasana baru bagi masyarakat Desa Apung, dimana masyarakat dapat beraktivitas pada malam hari dan dapat mengerjakan pekerjaan rumah pada malam hari. Masyarakat sangat terbantu dengan adanya listrik tersebut karena dapat mendukung pertumbuhan ekonomi masyarakat Desa Apung.

Pendapatan masyarakat Desa Apung meningkat karena disebabkan keberadaan perusahaan batubara. Upah yang diperoleh ketika masyarakat bekerja di perusahaan lumayan besar dan dapat memenuhi kebutuhan masyarakat. Upah yang diperoleh digunakan untuk kebutuhan sehari-hari seperti makanan pokok dan kebutuhan seperti motor dan alat-alat elektronik. Masyarakat juga dapat menabung dengan pendapatan yang diperoleh di perusahaan.

Dampak positif keberadaan pertambangan batubara di desa Apung didukung dengan pendapat Musthopa (2008)(Fitriyanti 2016). menjabarkan potensi manfaat ekonomi dengan hadirnya pertambangan dalam beberapa hal sebagai berikut : (1) Menjadi pionir roda ekonomi, (2) Mendorong pengembangan wilayah (3) Memberikan manfaat ekonomi regional dan nasional (4) Memberikan peluang usaha pendukung (5) Pembangunan infrastruktur baru (6) Memberikan kesempatan kerja (7) Membuka isolasi daerah terpencil (8) Meningkatan ilmu pengetahuan dengan transfer teknologi.

Ada beberapa sumbangan dan batuan yang dberikan oleh perusahaan batubara dalam meningkatka kesejahtraan dan perekonomian masyarakat desa Apung, diantaranya yaitu: (1) Budidaya Ayam dan ikan lele, (2) memberikan bibit jeruk kepada masyaraat petani(3) memberikan bibit singkong gaja dan kemudian dijual kembali keperusahaan, (4) memberikan bantuan air bersi (penampung air), (5) memberikan bantuan sosial berupa sembako minyak goring, beras, dll (6) membangun infrastruktur berupa jalan dan infrastruktur lapangan olahraga, (7) memberikan bantuan pada saat ada kerja bakti/umum di desa Apung.

c. Meningkat usaha masyarakat lokal

Perusahaan batubara di Desa Apung bertanggung jawab dalam meningkatkan usaha masyarakat dengan memfasilitasi sarana pembangunan bagi kepentingan masyarakat. Usaha yang meningkat ketika perusahaan ada di Desa Apung yaitu usaha sembako terus melonjak naik dan toko/atau jualan masyarakatpun semakin bertamba, usaha depo air, dimana usaha depo air masyarakat bekerjasama dengan perusahaan batubara, masyarakat yang menyediakan air minum untuk perusahaan. Selain itu, usaha yang terus meningkat dengan adanya perusahaan batubara yaitu ketring.

Sebelum adanya perusahaan batubara, masyarakat tidak ada usaha di bidang ketring, namun dengan adanya perusahaan batubara, masyarakat Desa Apung diberdayakan untuk membuka usaha mandiri berupa ketring. Usaha ketring bekerjasama dengan perusahaan, dimana ketring yang ada di Desa Apung menyediakan makanan bagi perusahaan batubara. Jadi setiap hari secara bergatian usaha ketring mengantar makanan kepada perusahaan batubara. Usaha ketring tersebut tentu membawa dampak yang sangat baik bagi masyarakat Desa Apung karena adanya peningkatan usaha dan mengurangi tingkat pengangguran di Desa Apung.

d. Pembangunan infrastruktur 
Keberadaan kegiatan tambang batu bara di Desa Apung diikuti dengan pembangunan infrastruktur, seperti jalan, sekolah, sarana ibadah dan lainnya. Keberadaan infrastruktur yang dibangun oleh perusahaan batubara dinikmati oleh masyarakat yang berada di lingkar tambang maupun di luar wilayah pertambangan. Perusahaan batubara di Desa Apung sudah banyak memberikan sumbangan ataupun membangun sarana dan prasarana di desa, perusahaan memberikan fasilitas yang dapat digunakan oleh masyarakat untuk meningkatkan kesejahteraan masyarakat. Salah satu sarana yang dibangun oleh perusahaan yaitu membangun dan memperbaiki jalan masyarakat Desa Apung.

Adanya pembangunan desa/fasilitas masyarakat yang bersifat sosial dan berguna untuk masyarakat banyak khususnya masyarakat yang berada di sekitar perusahaan tersebut. Seperti yang dirasakan oleh masyarakat Desa Apung mendapatkan kemudahan dalam bertransportasi menuju kota. Adanya infrastruktur jalan yang baik, masyarakat dengan mudah untuk menjual hasil pertanian kekota dan masyarakatpun muda pergi berobat kekota.

Keberadaan perusahaan batubara di Desa Apung membawak dampak yang sangat besar terutama terhadap sarana dan prasarana. Banyak hal yang dibuat atau dibangun oleh perusahaan batubara yang dapat dimanfaatkan oleh masyarakat desa untuk meningkatkan kesejahtreraan masyarakat yaiti: (1) pembuatan jalan poros desa antara desa, (2) perbaiki jalan desa, (3) pembangunan sarana olahraga sepakbola, (4) penyediaan sarana air bersih.

\section{Dampak Negatif}

Dampak negatif yang ditimbulkan perusahaan batubara akibat aktivitas pertambangan batubara merupakan suatu keadaan yang merugikan masyarakat desa Apung secara langsung ataupun tidak langsung. Akibat yang ditimbul secara tidak langsung merupakan suatu kerugiatan yang akan ditimbulkan oleh perusahaan, dimana masyarakat mendapatkan kerugian tersebut dimasa yang akan datang. Salah satunya yaitu bekas lobang galian perusahaan batura yang dibiarkan menganga sehingga lahan tersebut tidak dapat digunakan kembali oleh masyarakat sebagai lahan produksi. Tetapi jika ditumbun dan dilakukan penghijauan kembali, tentu tidak akan berdampak negatif bagi masyarakat Desa Apung.

Dari hasil penelitian yang diperoleh ada beberapa dampak negatif yang ditimbulkan oleh perusahaan batubara sehingga merugikan kehidupan sosial ekonomi masyarakat desa Apung sebagai berikut:

a. Penebangan hutan untuk kegiatan pertambangan

Hutan di sekitar Desa Apung semakin sempit karena keberadaan pertambangan batubara, aktivitas pertambangan batubara menggambarkan kondisi hutan saat ini semakit menipis dan terjadinya perubahan lingkungan akibat pertambangan. Perubahan ekosistem terhadap plora dan fauna mengakibatkan kondisi semakin gersang. Aktivitas pertambangan yang meninggalkan kubangan memberikan dampak kepada lingkungan sekitarnya karena tidak dapat dijadikan lahan produksi.

Dampak yang keberadaan ertambangan batubara di desa Apung sesui dengan pendapat(Soerjono 2001) industri pertambangan juga berpotensi merusak lingkungan sosial, yaitu nilai-nilai sosial budaya lokal dan ekonomi masyarakat yang bermukim di wilayah tambang, mempengaruhi pola kepemilikan lahan, pemanfaatan dan penguasaan 
sumberdaya alam, pertumbuhan dan perkembangan fasilitas sosial yang pada gilirannya menurunkan tingkat kehidupan sosial dan ekonomi masyarakat.

Keberadaan perusahaan batubara berdampak pada eksistensi hutan yang ada di lokasi aktivitas perusahaan batubara. Hutan dan lahan yang dimanfaatkan oleh masyarakat Desa Apung merupakan areal lokasi perusahaan untuk digarap, karena lahan tersebut masuk dalam perizinan dari pemerintah untuk perusahaan batubara. Masyarakat yang memiliki lahan pertanian diarea perizinan pertambangan batubara tentu membuat masyarakat dilemma untuk menjual lahan. Karena desakan ekonomi, masyarakat menjual lahan kepada perusahaan dan berdampak pada penyempitan atau berkurangnya produksi pertanian.

b. Pencemaran lingkungan

Dampak negatif yang dirasakan oleh masyarakat secara langsung ataupun tidak langsung yaitu pencemaran air bersi. Beberapa aliran sungai yang ada di Desa Apung sekarang ini semakin keru dan hal ini juga menjadi penyebab keberadaan pertanbangan batu bara. Pencamaran secara langsung yang dirasakan oleh masyarakat Desa Apung yaitu debu karen lalulalang kendaraan perusahaan batubara yang menyebabkan polusi udara. Pengaru debu atau polusi undara tentu berdampak pada kesehatan masyarakat sehingga dapat merugikan masyarakat dalam kesehatan ataupun ekonomi.

Perusahaan batubara jauh dari pemukiman masyarakat dan debu tidak sampai ke rumah, tetapi jalan yang dilalui kendaraan perusahaan batubara yang menjadi permasalahan karena jalan perusahaan tebal dengan debu, apa lagi kalau dimusim kemarau. Untuk mengatasi debu yang mejadi polusi udara, perusahaan berusaha untuk menyiram jalan sehingga jalan yang dilalui tidak berdebu. Untuk mengatasi supaya tidak terjadai masalah terkait dengan air bersi, perushaan batubara berupaya untuk membuat paret sehingga air paret tidak menuju kesungai yang dimanfaatkan oleh masyarakat.

Menurut (Teuku Ade Fachlevi, Eka Intan Keumala Putri 2015) pertambangan menyebabkan kerusakan lingkungan karena melakukan kegiatanpembukaan lahan yang luas, menggali lubang yang dalam dan memindahkan tanah dalam jumlah besar. Selain itu, kegiatan pertambangan batubara dapat mengakibatkan masyarakat di sekitar terkena gangguan kesehatan berupa gangguan pernafasan akibat debu.

Dapat dijelaskan bahwa aktivitas pertambangan sangat indentik dengan pencemaran lingkungan yaitu polusi udara, dimana debu yang ditimbulkan merupakan hasil dari kegiatan pertambanagan. Dubu aktifitas pertambangan batubara sangat barbahaya bagi kehidupan masyarakat. Oleh karena itu masyarakat yang berada di lokasi pertambangan batubara dianjurkan untuk menggunakan penutup hidung/masker.

\section{PENUTUP}

Dampak pertambangan batubara bagi kehidupan sosial ekonomi masyarakat di Desa Apung yaitu keberadaan pertambangan batubara memberikan dampak positif terhadap sosial ekonomi masyarakat Desa Apung mencakup tersedianya lapangan pekerjaan bagi masyarakat setempat, meningkatkan ekonomi masyarakat lokal dengan cara memberikan bantuan: (1) budidaya ayam dan ikan lele, (2) memberikan bibit jeruk kepada masyaraat petani(3) memberikan bibit singkong gaja, (4) memberikan bantuan air bersi (penampung air), (5) memberikan bantuan sosial berupa sembako minyak, (6) membangun inprastruktur berupa 
jalan dan infrastruktur, berupa perbaikan badan jalan desa, membuat jalan antara desa dan membangun lapangan olahraga, (7) memberikan bantuan pada kerja bakti/umum di desa Apung. Dampak positif selanjutnya yaitu meningkat usaha masyarakat lokal yaitu usaha sembako terus melonjak naik dan toko/atau jualan, meningkatkan usaha depo air, dan membuka usaha ketring.

Dampak negatif yang diakibatkan adanya perusahaan pertambangan yaitu, penebangan hutan, hilangnya flora dan fauna, lahan untuk kegiatan pertanian berkurang, pencemaran terhadap beberapa aliran air, dan debu atau polusi udara.

\section{DAFTAR PUSTAKA}

Djajadiningrat, surya. 2001. Untuk Generasi Masa Depan, Pemikiran, Tantangan Dan Permasalahan Lingkungan. Bandung: ITB.

Fatmawati;Budiman;Dyastari, Letizia. 2017. "Dampak Lingkungan Galian Tambang Sangatta Utara Kabupaten Kutai Timur.” 6(2):553-66.

Fitriyanti, Reno. 2016. "Pertambangan Batubara: Dampak Lingkungan, Sosial Dan Ekonomi." JUrnal Redoks 1(1).

Hs, Salim. 2012. Hukum Pertambangan Mineral \& Batu Bara. Jakarta: Sinar Grafika.

Komariah, Aan dan Santori, Dam'an. 2010. Metodologi Penelitian Kualitatif. Bandung: Alfabeta.

Moleong, Lexyj.2007. Metodologi Penelitian Kualitatif. Bandung: Remaja Rosdakarya.

Muchjidin. 2006. Pengendalian Mutu Dalam Industri Batu Bara. Bandung: ITB.

Otto, Soemarwoto. 2009. Analisis Mengenai Dampak Lingkungan. Yogyakarta: Gadjah Mada University Press.

Siska. 2013. "DAMPAK Industri Batubara Terhadap Sosial Ekonomi Masyarakat Di Sekitar Desa Jembayan Kecamatan Loa Kulu Kabupaten Kutai Kertanegara.” 1(2):473-93.

Soerjono, Soekanto. 2001. Sosiologi Suatu Pengantar. Jakarta: Raja Gravindo Persada.

Sugiyono. 2013. Metode Penelitian Pendidikan.Pendekatan Kuantitatif, Kualitatif, Dan $R \& D$. Bandung: Alfabeta.

Sugiyono. 2016. Metode Penelitian Kuantitatif,Kualitatif, Dan R\&D. Bandung: Alfabeta.

Teuku Ade Fachlevi, Eka Intan Keumala Putri, Sahat M. H. Simanjuntak. 2015. "Dampak Dan Evaluasi Kebijakan Pertambangan Batubara Di Kecamatan Mereubo.” 2(2):17079. 